\title{
France's Marcoule Nuclear Site: A History of Transition from Military to Civilian Use
}

\author{
Chieko Kojima
}

\begin{abstract}
French nuclear research began for military purposes and then further developed for business. This article traces the history of French nuclear development from the establishment of the French Atomic Energy Commission in 1945 to the present by dividing this period into six phases. Contrary to previous studies which focus on certain periods, seventy years of French nuclear history is investigated here. It describes the transition from military to civilian use, the development of the nuclear fuel cycle including the fast breeder reactor, spent nuclear fuel reprocessing, and disposal research. Additionally, based on a historical case study of the Marcoule site, the oldest nuclear site in France, this article shows that France will rely on back-end nuclear technology to survive in the twenty-first century.
\end{abstract}

Keywords history of nuclear development, France's nuclear policy, nuclear fuel cycle, spent nuclear fuel reprocessing, fast breeder reactor

\section{Introduction}

As of January 2019, there are 450 operational nuclear power plants around the globe with a total capacity of $399,094,000 \mathrm{~kW}$ of electricity. Fifty-eight of these are in France, a country with a total capacity of $63,130,000 \mathrm{~kW}$, the second largest in the world (JAIF 2019). France gets more than 70 percent of its power from nuclear sources and hence can be called a major nuclear power. Why did France expand the country's use of nuclear energy? Why dose France continue to develop nuclear energy after the Fukushima Daiichi nuclear accident? This article aims to investigate the answers to these questions from a historical point of view. It is based on not only historical documents but also on study tours to a French nuclear site as well as interviews with French nuclear engineers.

Firstly, a look at the historical development of French nuclear power generation is provided. Next, the Marcoule Nuclear Site ("Marcoule") is used as an example and a discussion of its historical role in French nuclear energy 
development is given. Then, a review based on information gained from visiting parts of the facilities at Marcole is made.

\section{Historical Development of French Nuclear Power Generation}

Phase I: 1945-1950

Before World War II, crucial research that contributed to releasing energy from the atomic nucleus was conducted in France. Henri Becquerel (1852-1908) discovered radiation in 1896, Marie (1867-1934) and Pierre Curie (1859-1906) discovered new radioactive elements in 1898, Frédéric Joliot-Curie (1900-1958) and Irène Joliot-Curie (1897-1956) discovered artificial radioactivity in 1934, while Frédéric Joliot-Curie, Hans von Halban (1908-1964), and Lew Kowarski (1907-1979) proved the potential for a nuclear chain reaction. Furthermore, during the war, Halban, Kowarski, and Bertrand Goldschmidt (1912-2002) took heavy water from France to Great Britain to work on the development of the atomic bomb, then went to Canada as part of the British team participating in the Manhattan Project (Goldschmidt 1967, 65-93).

Although the foundation of nuclear research was set down in France, it became difficult for France to develop nuclear energy independently due to the devastation suffered under German occupation. Nevertheless, post-war France did forge ahead with nuclear energy development.

On October 18, 1945, Charles de Gaulle (1890-1970) founded the Commissariat à lénergie atomique (the French Atomic Energy Commission: CEA) as a civilian organization to take charge of nuclear energy development. The government appointed two people to head the CEA, one responsible for administering government finances and another with the authority to lead the scientific and technological aspects. The former was the Minister for Reconstruction Rauol Dautry (1880-1951), while the latter role was given to Frédéric Joliot-Curie.

Having no technological partnership with Britain or the United States, the CEA could not acquire the uranium resources that those countries had monopolized. But in 1946, the CEA was able to secure about 10 tons. Most of this uranium had been hidden in Morocco by Frédéric Joliot-Curiet during World War II, while the remainder was uncovered at Le Havre Station right after World War II. At the time, 10 tons of uranium was enough for about three years of nuclear research in France (Goldschmidt 1987, 364-365). France also preferentially received several tons of heavy water produced in Norwegian facilities.

It was the restrictions imposed by the availability of the materials that determined the type of the first French nuclear reactor. Called Zoé (puissance zero, oxyde d'uranium et eau lourde), this reactor was different from the nuclear 
reactors used in America, ${ }^{1}$ as it used uranium oxide as its fuel, had a very small capacity to produce heat, and used heavy water as its neutron moderator.

Initially, the CEA poured most of its efforts into uranium exploration and mining. The French Département des Recherches et Exploitations Minières (Department of Mineral Resources: DREM) was set up within the CEA to pursue the exploration and mining of uranium within France and its overseas territories. Then in the fall of 1948, France's first high-grade uranium ore was discovered in Crouzille in south-central France (Lovéreni 1996, 28-29). The lack of fossil fuel resources prompted the desire for energy self-sufficiency through domestic uranium mining and the discovery at Crouzille was one reason for the continued development of nuclear energy in France.

On December 15 of the same year, Zoé at Châtillon began operations, the first successful French nuclear reactor, causing a sensation throughout the country. Then in 1949, the national center for nuclear research was set up in Saclay, and it was decided to construct a second heavy water reactor after Zoé. In November 1948, France successfully separated a few milligrams of plutonium at its uranium refinery at Bouchet. The CEA had enjoyed a steady stream of achievements since its establishment, and at the end of 1949 it was employing some 1,400 people and its budget was increased to 7.3 billion old francs (CEA 1952, 99, 107).

However, around this time, the behavior of CEA chief Joliot-Curie had become a serious problem. The Cold War had intensified, and, as a member of the Communist Party, Joliot-Curie had become more politically active and had attracted the ire of the French government. Thus, on April 28, 1950, the government relieved Joliot-Curie of his duties stating that however brilliant his scientific achievements may have been, he was incompatible with his position at the CEA due to his support of various resolutions adopted at communist party conventions (Goldschmidt 1967, 188). Joliot-Curie's dismissal had a huge impact on the CEA, putting the brakes on the extremely rapid developments that the organization had undertaken up to that point, while an increase of members to the nuclear energy committee meant that scientific representation on the committee was now in the minority.

This first phase can be called an era of scientific leadership under JoliotCurie. Having begun as a civilian organization, the CEA scientists were dedicated to researching non-military uses of nuclear power. This was a triumphant period of success with the first nuclear reactor, the discovery of uranium within France, and the extraction of plutonium.

Phase II: 1951-1960

Although opinions within the government on who should succeed Joliot-Curie were divided, Francis Perrin (1901-1992) was entrusted with the job in April 1951 (CEA 1970, 2). Then in August of the same year, Dautry, the politician 
who had been responsible for the financial administration of the CEA, suddenly died, putting the CEA once again in a potentially dangerous political position. However, trouble was circumvented by up-and-coming cabinet politician and Minister of State Félix Gaillard (1919-1970), himself an enthusiastic proponent of nuclear energy development. Gaillard appointed Pierre Guillaumat (1909-1991), an accomplished mining engineer who had specialized in oil problems up to that time to succeed Dautry. With the cooperation of Guillaumat, Perrin established the first French five-year plan for nuclear energy (Goldschmidt 1967, 192-194). This five-year plan was passed by the National Assembly in July of 1952 with a budget of 377 billion old francs (Perrin 1953, 111-112). Then in October of the same year, EL2, the country's second heavy water reactor, began operations at CEA in Saclay, turning around the stagnant mood in nuclear energy development that followed the dismissal of Joliot-Curie into one of progress.

In August 1955, the first international "Atoms for Peace" conference, which was held in Geneva (the Geneva conference), further promoted the development of nuclear energy. As the idea was gaining momentum that nuclear energy would play a major role in supplementing the energy supplies of the future in France and elsewhere, the country established an atomic energy advisory council, Production d'Electricite d'Origine Nucleaire (PEON), in the same year.

In January 1956, the French graphite-moderated gas-cooled reactor (Uranium Naturel Graphite Gaz:UNGG) G1 began operations at Marcoule. Contruction of G1 was carried out by the CEA although it was jointly developed by Eléctricité de France (Electricity of France: EDF), after a decision was made that that the organization should participate in nuclear energy development from 1952. The companies S.A.C.M, Alsthom, S.F.A.C., and Rateau also participated in the development. Initially EDF's participation in nuclear energy development was carried out under the direction of the CEA; however, EDF later took responsibility for overall planning and developed the EDF1 and EDF2 reactors.

During the Suez Canal Crisis, Britain, France, and Israel sent troops to the area in July 1956. Even though the troops were completely withdrawn by 1957, the conflict had underscored the importance of nuclear energy and spurred its development all over the world (Goldschmidt 1967, 228). At the time, France had been enduring the dominance of major international oil companies for the supply of crude oil, and the idea that it could avoid dependency on other countries for its energy became even stronger. Then in July 1957, the second five-year plan for nuclear energy was passed. This time the budget was 500 billion old francs (RFC 1957, 30), a thirteen fold increase on the budget of the country's first five-year nuclear energy plan.

One of the reasons that the second five-year plan had such an enlarged budget was that the CEA had begun military research. Although similar in design to the G1 plutonium production reactor, the country's G2 and G3 reactors also included power generation capabilities and began operations in 1958 and 1959 
respectively. Military research was carried out using plutonium produced by these reactors, leading to the first French nuclear weapons test in the Sahara Desert on February 13, 1960.

This second phase was characterized by proactive advancements in nuclear energy development as France introduced its five-year nuclear energy plans while riding on the global nuclear energy boom. And no longer exclusive to the CEA, EDF and private companies had also begun to participate in nuclear energy development. Moreover, nuclear energy development had another objective: to produce plutonium in reactors for the first French nuclear weapons tests in 1960. The CEA's involvement in military research in this second phase was a complete turnaround from the first phase in which CEA was run by Joliot-Curie, a man who was opposed to the possession of nuclear weapons (Scheinman 1965, 97).

Phase III: 1961-1969

During phases I and II, the French development of nuclear energy progressed independently in spite of the effects of the worldwide nuclear energy boom and the Cold War. However, French nuclear energy policies were influenced by the American nuclear industry from the latter half of the 1960s.

From the outset, UNGG type reactors were adopted in France, and the 1964 PEON report proposed that UNGG development should continue (Morsel 1996, 719). However, in the United States, Westinghouse had developed its pressurized light water reactor (PWR), while General Electric had developed its boiling water reactor (BWR). One of the reasons France had not chosen to use PWR or BWR light water reactors was because light water reactors used enriched uranium as fuel. At the time, enriched uranium refinement was a military secret, and among Western countries only the United States had the production technology. So, respecting its own autonomy in nuclear energy development, France chose to go down the road of developing UNGG reactors using natural uranium as the nuclear fuel to avoid reliance on the United States for enriched uranium.

Although the Suez Canal Crisis had alerted the world to the need to secure energy supplies including nuclear energy, new crude oil resources were subsequently discovered in the Sahara desert, tanker costs fell, and the stance of Middle Eastern oil producing countries softened leading to crude oil oversupply and a temporary stagnation in nuclear energy development (Goldschmidt 1984,156). However, the situation changed in 1964 when the economics of nuclear energy began to be asserted in developed countries. Data based on operational reactors in the United States and Great Britain presented at the third Geneva conference held at the end of 1964 showed projections on how reactors started up at the end of the 1960s with the capacity to meet demands for electricity in large cities would outperform conventional thermal power generation. By the end of 1965, confidence in the economics of nuclear energy had spread through the American electricity industry, and from 1966 onward the American industry 
underwent an unprecedented nuclear energy boom, with orders for nuclear power facilities reaching 10 billion francs by 1966 (Goldschmidt 1967, 268). At the same time, the American nuclear energy industry began proactively selling its light water reactors around the world, and received 235 orders in ten years starting from the mid-1960s (Debeir, Deléage, and Hémery 1986, 269).

France also found itself caught up in these trends, but they coincided with trouble occurring for the first time with an EDF reactor. The EDF1 and EDF2 UNGG reactors had performed smoothly, however the similar EDF3 reactor malfunctioned in October 1966, and then again in March 1968. Thus, a heated debate ensued in France in the latter half of the 1960s on whether the country should continue using UNGG reactors into the 1970s or build PWR facilities (Hecht 1998, 271-323). This battle was said to have been waged between the CEA which argued for UNGG reactors and the EDF which preferred PWR technologies (Morsel 1996, 721). In the end, PEON selected PWR technology (PEON 1968, 57) because globally the most experience was in PWR operation, the United States was anticipating cost reductions due to the large number of PWR orders, and because there could be some relaxation on enriched uranium, over which the United States had a monopoly, since it would be producible in Europe with these developments (Goldschmidt 1984, 197). It was not that France had had no experience developing PWR. The country had already been involved in joint development of the Chooz A1 PWR with Belgium in 1960, while in 1964 a French-built PWR designed for nuclear submarines began operations. As for enriched uranium too, France had begun operations of a military uranium enrichment plant at Pierrelatte in 1965, which produced enriched uranium in 1967. These facts also influenced the decision to shift to PWR.

It was the demise of the dominance of the CEA over nuclear energy development and de Gaulle's support for it that brought an end to UNGG, a technology independently developed in France. Georges Pompidou (1911-1974) who served as president after de Gaulle in 1969, supported the PWR technology selected by EDF and PEON, and thus American technology was eventually brought to France.

French nuclear energy development in the 1960s was not just consumed by discussions on reactor selection. The country had progressed with fast breeder reactor research, and in 1967 began operating its Rapsodie fast breeder reactor at Cadarache. France also conducted a megaton-class hydrogen bomb test at Fangataufa atoll in 1968, and in 1969 succeeded in the world's first glasssolidification high-level waste processing at Marcoule, making the 1960s the era of essential technical developments.

Phase IV: 1970-1990

EDF ordered its first PWR from the United States in 1970. Using both American and French capital, Framatome, a company established in 1958, developed PWR 
construction technology under license from Westinghouse, and held a monopoly on PWR construction in France with plans to construct eight billion watts of PWR capacity within five years (Bonnet 1982, 123; Framatome 1995, 50). Six light water reactors and a European uranium enrichment plant to be built in Fessenheim and Bugey were included in the fifth five-year nuclear power plan, of which preparations were ongoing in 1970 (Capelle-Blancard 1999, 31). This meant that France already had plans on the table to increase production of light water reactors right before the first oil shock of 1973.

When this oil shock came, France's dependency on overseas energy supplies was approximately 80 percent, with approximately 60 percent of its primary energy dependency being on petroleum. In 1973, France imported 14.5 billion francs worth of petroleum from OPEC, a figure which ballooned to 43 billion francs the following year. In March 1974, Prime Minister Pierre Messmer (19162007) announced a plan to start building 16,900 MW light water reactors within two years to be completed by 1978-1980. Even when Valéry Giscard d'Estaing (1926-) took over the presidency from Pompidou, policies to drive nuclear power were put in place with the Messmer plan being passed in 1975. This momentum was further accelerated by the second oil shock of 1978 during which the rush to build nuclear power in France continued. By the beginning of the 1980s, there were eighteen nuclear power plants operating in France, with a further thirtythree under construction (ibid., 32-33). In 1973, a mere 8 percent of France's electricity was produced from nuclear power, but by 1990 this had increased to 75 percent, representing a year-on-year increase of $19.7 \%$. During the same period, electric power generation from crude oil dropped from 43 percent to 4 percent, which was purely a result of the French government's push to develop nuclear power in response to the oil shocks (Morsel 1996, 683-694).

During the same period, France poured efforts into reprocessing and fast breeder reactor research. Since research in these fields had not even progressed in the United States, France's approach was ambitious (Bonnet 1982, 131). The Usine Plutonium (UP) 1 reprocessing plant had been operating at Marcoule since 1958 , and research into low and medium level waste processing had begun at La Hague in the latter half of the 1960s. High-level waste processing then began at La Hague between 1976 and 1977. At the end of 1973, the 250 MW Phoenix fast breeder reactor also began operation at Marcoule. Then in 1977, construction of the 1.2 GW commercial Super Phoenix began at Creys-Malville, with operations commencing in 1985.

New institutions and CEA-affiliated companies were established with this diversification of nuclear power development. A nuclear safety and protection institute, Institut de Protection et de Sûreté Nucléaire (ISPN), was established in 1976 to deal with nuclear safety and environmental issues, while Compagnie Générale des Matières Nucléaires (COGEMA) was established to conduct uranium exploration and mining, conversion, enrichment, and reprocessing 
operations etc. In 1979, Agence nationale pour la gestion des déchets radioactifs (ANDRA) was established to manage radioactive waste.

This fourth phase was surely the golden era of the French nuclear power industry, but criticism was raised of EDF's extreme nuclear power policies at the time of the 1981 presidential and the National Assembly elections, and the administration of François Mitterrand (1916-1996) that came to power in October of the same year cut back on nuclear power plans to counterbalance the fall in energy demand. However, the Mitterrand administration did not change the basic policy of promoting nuclear power (Goldschmidt 1984, 280-281). Successive administrations in France have always maintained the promotion of nuclear energy even after the Chernobyl nuclear accident in 1986.

In May 1986, France established the Commission for Independent Research and Information on Radioactivity (Commission de Recherche et d'Information Indépendantes sur la Radioactivité: CRIIRAD) centered on scientists who were alarmed by the information provided in the aftermath of the Chernobyl disaster. This organization was set up as an environmental protection NGO to protect citizens from radiation, and monitor radiation pollution from nuclear facilities such as those in the Rhone River area and Marcoule. It measures and analyzes radiation on requests from local authorities, etc. (JAIA 2016).

\section{Phase V: 1991-2000-Nuclear Power Development Stagnates}

Nuclear power development stagnated following the 1986 Chernobyl nuclear accident and discussions in the 1990s on banning nuclear testing leading to the adoption of the Comprehensive Test Ban Treaty (CTBT) by the United Nations (UN) General Assembly in September of 1996. There were in fact only three countries that embarked on new nuclear development in the 1990s: Mexico (1990), China (1994), and Romania (1996). By the 1980s in France, nuclear facility projects to cover the country's electricity demand were completed and nuclear reactor orders to Framatome fell dramatically. The proportion of electricity generation covered by nuclear plants reached 75 percent in 1990 after which it remained unchanged, and EDF stopped new nuclear-related engineer recruitments. $^{2}$

As well as the fall in employment, nuclear development also experienced unfavorable conditions. France had been a global leader in fast breeder reactor research, but a decision was made to decommission the Superphénix demonstration fast breeder reactor, which had reached criticality in 1985. Due to a sodium leakage incident and generator accident at Superphénix in 1987 and 1990, the Socialist Party Prime Minister Lionel Jospin set down a policy to decommission the facility in June 1997 to meet a promise made to the Green Party. In December 1998, the ordinance to close the facility was announced, and work began on December 1, 1999 to remove the fuel from the reactor core. As of December 2016, work to dismantle Superphénix and decommission the reactor 
are ongoing (Guidez 2016, 365-368). In addition to the Superphénix reactor decommissioning, the Phénix prototype fast breeder reactor reached its planned 20 -year life-span in 1994, but was extended to 2009 with safety modifications and retrofitting.

Also, the Waste Management Act (Bataille's law) passed in December 1991 aimed to address the problem of processing and disposing of spent nuclear fuel through research on radioactive waste management. Bataille's law was established because the French government decided to establish four deep geological disposal research facilities for nuclear waste between 1987 and 1989 without obtaining prior community agreement. Those plans were scrapped due to extremely strong protests from local residents. After that, Member of Parliament Christian Bataille headed investigations which lead to the establishment of Bataille's law. This law applies to management of all of France's nuclear waste, and addresses potentials for deep geological disposal. To guarantee the scientific appraisal under Bataille's law, the National Evaluation Committee (La Commission Nationale d'Evaluation: $\mathrm{CNE}$ ) was set up consisting of specialists completely independent of the French Nuclear Safety Authority (ASN) and the French National Radioactive Waste Management Agency (ANDRA) (COE-INES 2007, 3). In this way, France has faced the back-end problem of nuclear waste since 1990. But, for the French government, the selection of the final disposal sites proved to be far more difficult than imagined.

In addition to deep geological disposal, it was also decided under Bataille's law to research fission and conversion of long-lived radio nucleotides, and longterm above-ground storage. This research was initially started at the beginning of the 1980s at a research facility called Atalante in Fontenay-aux-Roses, but was transferred to Marcoule in 1985. Thus, Marcoule was given a new mission as a research institute for the long-term storage of left over spent nuclear fuel.

\section{Phase VI: Beyond 2001-The Nuclear Renaissance and the Fukushima Daiichi Nuclear Plant Accident}

In 2001, the Bush administration in the United States announced proactive governmental support for nuclear power generation. Against this backdrop, a so-called "nuclear renaissance" was advocated by the American nuclear energy industry, and this movement spread to nuclear industries around the globe. The nuclear renaissance promoted nuclear power generation due to the necessity to reduce consumption of fossil fuels because of their high price and to prevent global warming (Yoshioka 2009, 74). In August 2005, the Energy Policy Act passed in the United States detailed cooperative support in terms of both finances and systems to encourage power companies to build new nuclear power facilities. Then, to promote spent nuclear fuel reuse and as a nuclear nonproliferation measure, the U.S. Department of Energy (DOE) announced a new international framework called the "Global Nuclear Energy Partnership" (GNEP) for providing 
fuel for nuclear power generation to other countries in February 2006. While partner countries including Japan, the United Kingdom, and France supply fuel for nuclear power generation at a suitable price, this announcement could be interpreted as an indication of an American shift towards nuclear fuel reprocessing (Denki Shimbun Overseas Nuclear Power Coverage Team 2006, 4144).

Boosted by the tail wind of the nuclear renaissance, France strengthened its moves into overseas markets. As well as European operations, EDF is also involved with seventy-five group companies in a total of twenty-two countries in North America, Asia, and Africa, etc. The company has developed power generation-related services and consultancies in thirty-five countries, and most notably, it pioneered the nuclear power market in China. EDF teamed up with the Areva nuclear power group to provide total nuclear power project proposals, with EDF providing nuclear power generation operations technology and Areva providing hardware and equipment (ibid., 66-69). Areva was established in 2001 as a company largely owned by the French government, and is a major nuclear power corporation formed by grouping COGEMA, which is involved with uranium mining and spent nuclear fuel reprocessing, and Framatome, which manufactures nuclear reactors. Areva is an ambitious exporter of nuclear power plants to foreign countries, and its marketing efforts have been backed by the French president. In November 2007, President Nicholas Sarkozy visited China accompanied by forty CEOs of France's top companies including Areva, and closed an Euro $\$ 8$ billion contract to supply two of the latest PWR plants. Additionally, President Sarkozy visited countries such as the UAE, Algeria, and Libya to establish cooperative relationships on nuclear power generation issues (Yazawa 2008, 88-89). Notably, after the Fukushima Daiichi nuclear plant accident in March 2011, President Sarkozy and Areva CEO Anne Lauvergeon visited Japan to sell Areva decontamination equipment. ${ }^{3}$

Also after the March 2011 Fukushima Daiichi accident, the Socialist party leader François Hollande, who was advocating for reducing nuclear power generation, was elected by a narrow margin to replace President Sarkozy in the May 2012 elections. The "Energy Transition Law" was enacted under his administration in July 2015. This law involves expanded implementation of renewable energy, promotion of energy savings, a reduction in the share of nuclear power generation from 75 percent to 50 percent by 2025, and shutting down Fessenheim, the oldest nuclear power station in France, pledges made by President Hollande during his election campaign. However, Fessenheim was not shut down before Hollande finished his term as president, and future nuclear policy hinged on the results of the April-May 2017 French Presidential Election from which Hollande withdrew his candidacy. Although the French government began to show a proactive stance toward renewable energy in the twenty-first century, ${ }^{4}$ considering the history of nuclear power development 
in France, its policy appears to advocate a continuation of its expansion in the international nuclear power markets having earned trust for safety both in France and internationally. This implies a strategy of exporting nuclear power plants to countries newly developing nuclear power, and providing back-end technologies to existing nuclear countries like Japan and those in Europe.

French citizens have been surveyed regarding nuclear power by the French Ministry for Ecology, Sustainable Development and Energy. To the question "Three quarters of France's electricity comes from nuclear power. Considering all aspects, are you in favor or against nuclear power?" polled in July 2011, right after the Fukushima Daiichi accident, the number of those against quickly rose to 50 percent; although by January 2012, the number of those in favor had risen to 47 percent. In ten years, the percentage those in favor of nuclear energy have moved between the high forties and low fifties, and it appears that the psychological influence of the Fukushima Daiichi accident was temporary (Onishi 2013, 14). Nevertheless, the major impact of the Fukushima Daiichi accident on the opinions of the French people remains unchanged. Although French nuclear power plants operating since the 1970s and 1980s are slated for replacement in the 2020s, the biggest issue for French nuclear power policy in this regard is how to respond to the French citizenry.

\section{The History of the Marcoule Site}

The previous section outlined the history of French nuclear power generation development and described plutonium manufactured at Marcoule and used in France's first nuclear weapon test, UP1, the first French spent nuclear fuel reprocessing plant set up at Marcoule, the Phénix prototype fast breeder reactor that operated at Marcoule, and Atalante, a facility for researching spent nuclear fuel reprocessing and disposal which was transferred to Marcoule.

Marcoule started out as a military research facility, but later became a facility for civilian purposes promoting the nuclear fuel cycle and fast breeder reactor development, and was active in spent nuclear fuel reprocessing and disposal research. Thus, Marcoule is a microcosm that illustrates the history of nuclear power development in France.

This section discusses the history of nuclear development at Marcoule in three stages. Firstly, the plutonium production and reprocessing plant for military purposes. Secondly, the Phénix fast breeder reactor, and finally spent nuclear fuel reprocessing, disposal research, and reactor decommissioning measures. The following section reports on the Atalante laboratory researching spent nuclear fuel reprocessing and disposal and the decommissioning of the Phénix prototype fast breeder reactor. 


\section{Military Plutonium Production and Nuclear Fuel Reprocessing Plant}

The Beginning of Military Research: In April 1950, Frédéric Joliot-Curie, who was opposed to nuclear weapon development, was dismissed as the head of the CEA Science Department, after which the CEA began developing nuclear power for military purposes. Many scientists, including Frédéric Joliot-Curie's replacement as the head of the CEA Science Department Francis Perrin, advocated the use of nuclear reactors for peaceful purposes; although later, Yves Rocard, who played a central role in the development of France's nuclear weapons, said that the military use of nuclear power was in the national interest (Scheinman 1965, 123-124). The French Minister of State Félix Gaillard said "for France to become a modern nation, it is up to us" (CEA 1996, 52), and asserted that "the use of nuclear power will determine the future of France" (Hecht 1998, 60). As a result, a budget of 37.7 billion old Francs was approved for the first fiveyear plan for nuclear power in July 1952 for plutonium production and power generation research, and a target was set to produce $50 \mathrm{~kg}$ of plutonium annually for both public and military purposes. This five-year plan aimed to build three reactors, two of which were the G1 and G2 graphite-moderated gas reactors for producing plutonium, construction of which was supervised by Pierre Taranger who graduated from École Polytechnique (Mazzucchetti 2005, 6).

The Marcoule Site Decision: The G series reactors for producing plutonium, G1, G2, and G3, required a site with an abundant supply of water for the nuclear fuel reprocessing plant extracting the plutonium from the nuclear fuel used in those reactors. Hence, the Rhone River basin was considered for candidate sites. Marcoule was suitable because it is also in an area where the Mistral wind blows. Requirements also included solid ground and height to escape flooding. G1 construction director Taranger himself inspected the site, and in December 1952 the Marcoule site was formally selected (see Figure 1).

After construction began in January 1953, seventy-seven grape growers submitted a declaration protesting the construction in February. One of those opposed, Louis Anglezan, protested saying that "building a nuclear power facility only eight years after the Hiroshima bombing is unforgivable" (Mazzuccheri 2005, 13). However, in April 1953, the CEA-issued land acquisition ordinance came into effect, the agency won its cases in July and October of the same year at the Uzès District Court, but a settlement was reached to guarantee the rights of the viticulturists. Former soldier Robert Colson was instrumental in promoting the land. Colson had married a famous Marcoule local and had been living there since 1952, and owned a lot of the land. In June 1953, Colson became a director of preparing for the construction of the plutonium production facility at Marcoule and was a hugely influential figure during that period (ibid., 15). 
Figure 1. Current Nuclear Power Facilities in France

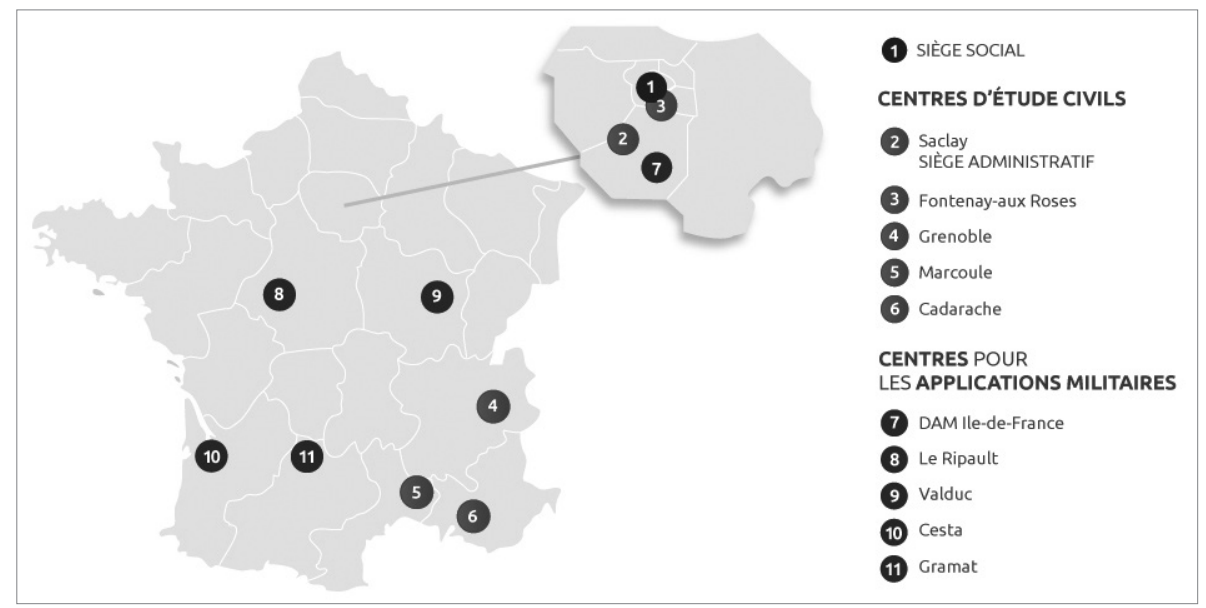

Note: (1) Headquarters, (2) to (6) Facilities for civilian uses, (7) to (11) facilities for military uses, (5) Marcoule

Source: CEA (2017)

first nuclear power five-year plan was amended; a budget was received from the French ministry to construct the G3 plutonium production reactor and acquire plutonium for military purposes through reprocessing spent nuclear fuel from that reactor. Then in October 1955, the plutonium production facility at Marcoule opened and Maurice Gervais de Rouville from the École Polytechnique assumed its directorship.

The CEA adopted a method of assigning each department with one company designated with a task and then integrating them to proceed with work. For example, the Schneider group subsidiaries such as SFAC and SACM for nuclear fuel, Alsthom for control and power equipment, La CITRA for concrete, and Saint-Gobain for radioactive waste deposit were adopted for the G1 reactor. As a result of these companies using other companies, there was a total of 350 companies involved in the construction of the plutonium production facility. These partnerships were reformed during construction of later French nuclear power plants-Chinon, Saint-Laurent, and Bugey-but they were originally formed around the Marcoule project.

The CEA and these companies proceeded with construction at breakneck speed. Generally there are delays in construction, but thanks to simultaneously driving research, parts production, and construction, the G1 project reached criticality in January 1956 after construction commenced in May 1954, having only experienced six days of delays. Construction of G2 began in September 1955, although detailed planning was not finalized until February 1956. G2 reached criticality in July 1958, and G3 reached criticality in June 1959. Guy Richard, 
Figure 2. "The Nuclear Centipede"

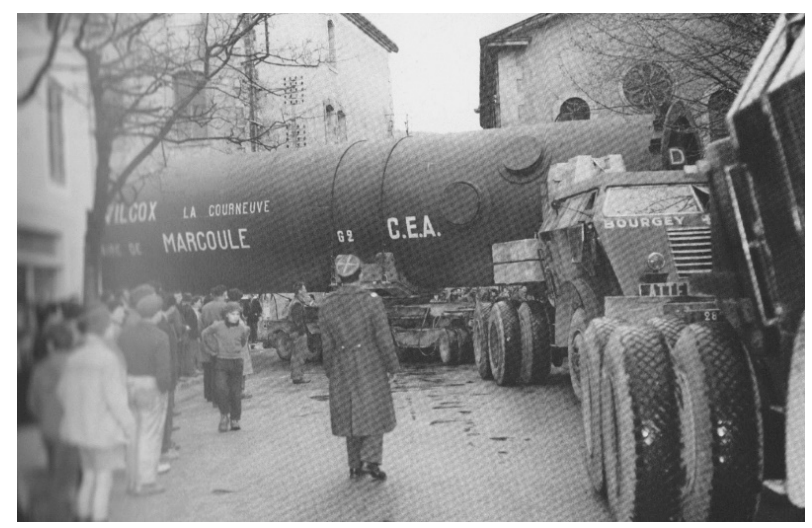

Source: Le Midi Libre (1957)

director of SACM, one of the companies involved in construction, described the conditions at the time as "twelve hours a day of labor from Monday to Saturday, and sometimes on Sunday as well. It was as if we were in a procurement boom preparing for war, with no limit to our budget. Essentially, we just completed the plan in a short period of time without the company really knowing how much cost was involved." Figure 2 shows CEA equipment being carried to Marcoule on February 26, 1957. This long train of trucks was dubbed the "nuclear centipede" (Mazzucchetti 2005, 14-17).

The most difficult aspect of developing the graphite-moderated gas reactor was plutonium extraction. France had first experimentally extracted several milligrams of plutonium in November 1949. From 1952, Bertrand Goldschmidt and Pierre Regnaut worked on plutonium extraction research, and in 1953 an experimental plutonium factory was built at Châtillon. However, that research was taken over by UP1, which began operating at Marcoule in July 1958 as France's first spent nuclear fuel reprocessing plant.

The first time spent nuclear fuel from G1 was brought to UP1 was in July 1958, and following from that the first plutonium ingot was produced in February 1959. France performed its first nuclear weapon test on February 13, 1960 in the Sahara using plutonium extracted from spent G1 nuclear fuel reprocessed at UP1. Without this plutonium production facility at Marcoule, France's first nuclear test would not have been possible.

The Decline of the Marcoule Site: The Marcoule plutonium production facility played a central role in the first French nuclear weapon test, and was a pioneer with its graphite-moderated gas reactor and reprocessing plant development. After the successful 1960 test, the Marcoule site began reprocessing spent nuclear fuel from the Chinon nuclear reactor run by EDF for civilian purposes in 1964 
(CEA 1964, 32), and produced 1,000 to 1,200 g plutonium ingots in 1965 (CEA 1970, 30).

With debate about the types of nuclear reactors in the latter half of the 1960s, the Marcoule site began to decline. From the 1970s onwards, the CEA asserted that graphite-moderated gas cooled reactors should be selected while EDF insisted on light water reactors. While the debate on reactor types progressed, the number of staff at the G1 graphite gas cooled reactor used for nuclear weapons testing was reduced from eighty-two to fifty-seven people, and in October 1968 G1 was decommissioned. The debate ended with France adopting light water reactors in 1969, and UP1, which was a reprocessing plant for graphitemoderated gas reactors, was hit hard by the decision.

This decision also entailed nuclear power facilities construction in other districts, which caused the presence of Marcoule to gradually fade. In 1960, construction on France's second reprocessing plant UP2 began in La Hague and commenced operation in 1967. After UP2 started running, spent nuclear fuel from EDF's Chinon reactor, which had been processed at UP1 at Marcoule, shifted to processing at La Hague. In 1961, a uranium conversion plant began operating at Pierrelatt, and in 1962 plutonium production for nuclear fuel began at Cadarache for Rapsodie, France's first fast breeder reactor. As a result, the 200 jobs that existed up to 1971 and the 300 to 400 jobs that existed between 1971 and 1975 at the Marcoule site were abolished, and many talented engineers were transferred to other sites. Marcoule's first director, Maurice Gervais de Rouville, called this period the "dark age" of Marcoule. Job losses at Marcoule resulted in demonstrations and strikes. In 1968 in particular on the tenth anniversary of UP1's first reprocessing, between 500 and 600 laborers demonstrated to protest against the top-down methods of the CEA and demand lower working hours, safety standards, and a retirement system. Then in December 1968, Gervais de Rouville resigned his directorship after serving for thirteen years since 1955 (Mazzucchetti 2005, 77-81).

\section{The Phénix Fast Breeder Reactor}

The Molbert Revolution: In December 1968, Gervais de Rouville's successor Michel Molbert arrived at Marcoule and began serving as director. Forty-year-old Molbert, former student of the Ecole Polytechnique, ran the Marcoule site with completely different methods than his predecessor. While following the policies of the CEA, Molbert was always willing to engage in conversations with the Marcoule staff and thus established a penetrative system of cooperation. In this way, Molbert took up the challenge of running a new organization and made an effort to acquire new customers beyond the French Defense Ministry and EDF by providing results of the research done at Marcoule to a wide range of industries involved in information processing, physical chemistry, and medicine (ibid., 8393). 
Also, maintaining a pioneering position, Molbert oversaw the construction of the Phénix prototype fast breeder reactor at Marcoule. Phénix construction began in 1968 and reached criticality in 1973, a period which overlapped with Molbert's tenure as director.

The History of the Phénix Development: Fast breeder reactor research began in France due to its close relationship with the G1 reactor constructed at Marcoule. According to Georges Vendryes $(1997,27)$, the so-called father of the fast breeder reactor, this research was conducted at Saclay by the physicists and engineers who had built the G1 reactor that reached criticality at Marcoule in 1956. Vendryes stated in an interview that he was involved in researching neutrons at G1, but the research group disbanded after the success of G1 and the same group members began researching fast breeder reactors (Kojima 2011, 65-86). During the G1 development, it was impossible to acquire enriched uranium in France and the French government did not want to rely on the United States for its nuclear fuel. So the G1 nuclear fuel was natural uranium. Because the purpose of the G1 was to produce plutonium, the shift to fast breeder research to acquire plutonium by high-speed neutron absorption in uranium 238 was a logical step following the G1 research. The construction of the Rapsodie fast breeder test reactor began in 1962 and reached criticality in January 1967 at Cadarache.

At Marcoule, the Phénix prototype fast breeder reactor construction began in 1968 and went critical in August 1973. At the time, Phénix was a fast breeder reactor operating stably at full power (Ferrair, Sugier, and Vautrey 1979, 586). In fact, Rémy Carle, who was in charge of planning Phénix, stated in an interview that he felt that with the success of Phénix, France was at the top of fast breeder reactor research (Kojima 2009, 1-39). In the United States, which had led fast breeder reactor research, research had stalled in the last half of the 1970s. Although France was a late starter, it began research with the Superphénix demonstration fast breeder reactor in the early 1970s. Carle's statement can be interpreted as an assertion that although France imported light water reactors from the United States, it had in fact beaten the United States with its fast breeder reactors which demanded higher levels of technology.

Phénix, which had been operating since 1974, was the only prototype fast breeder reactor in operation for thirty-five years even though it had experienced various incidents such as leakage of sodium coolant (Guidez 2013, 211-219). It was formally recognized by the American Atomic Energy Society as a nuclear historic landmark in FY 1997 (Sauvage 2009, 137). The Phénix prototype fast breeder reactor reached its planned twenty-year lifespan in 1994, but was extended with the decommissioning of the Superphénix demonstration fast breeder reactor. Superphénix reached criticality in Creys-Malville in September 1985, but due to incidents such as sodium leakages in 1987 and 1990 and a generator incident, the plant was slated for decommissioning in June 1997, and an 
ordinance to close the plant was announced in December 1998. Thus, the Phénix fast breeder reactor underwent safety modifications and retrofitting to extend its lifespan to 2009. When Phénix resumed operations in 2003, experiments were performed mainly on nuclear transmutation of minor actinoids and longlife radioactive wastes and irradiation for development of future gas-cooled fast breeder reactors. In other words, the experiments essentially planned for Superphénix were taken over by Phénix. ${ }^{5}$

After operations were halted in 2009, the spent fuel and sodium were removed from Phénix and sodium processing and other facilities were set up. The subsequent decommissioning is described as a case study below.

Spent Nuclear Fuel Processing, Disposal Research, and Decommissioning Equipment Spent Nuclear Fuel Processing and Disposal Research: Nuclear power development stagnated globally in the 1990s following the April 1986 Chernobyl nuclear accident and discussions in the 1990s on banning nuclear testing leading to the adoption of the Comprehensive Test Ban Treaty (CTBT) by the UN General Assembly in September of 1996. In France also, the necessity to build new nuclear power stations disappeared, and employment in the sector fell. However, it was also a period in which new back-end nuclear businesses began to flourish. Batailles law passed in December 1991 aimed to address the problem of processing and disposing of spent nuclear fuel through research on radioactive waste management. In addition to deep geological disposal, it was also decided to research fission and conversion of long-lived radio nucleotides and long-term above-ground storage. The studies began in the early 1980s at a research facility called Atalante in the Parisian suburb of Fontenay-aux-Roses, but Atalante was transferred to Marcoule between 1985 and 1992. Thus, Marcoule took over the job of researching the processing, disposal, and long-term storage of spent nuclear fuel left over from the past. The first spent nuclear fuel arrived in 1999, and in 2005 the LN1 facility was constructed mainly to study the chemical and physical chemistry of transuranic elements, while the DELOS facility began operations in 2008 to study the mineralization of liquid organic pollutants. Atalante currently consists of five buildings. Thus, as the world's leading research facility specializing in spent nuclear fuel reprocessing, disposal, and long-term storage, the American Nuclear Society formally recognized these facilities as nuclear historic buildings in 2013 (American Nuclear Society 2019).

Case Study of Atalante: This section provides a review based on information gained while visiting part of the Atalante facility at Marcoule in March 2015. Photography was forbidden, therefore photographs have been borrowed from the Revue générale nucléaire, the magazine of the Société Française d'Energie Nucléaire (SFEN - French Nuclear Society).

Atalante is an indispensable facility in France, a country which chose the 
Figure 3. Glove Boxes

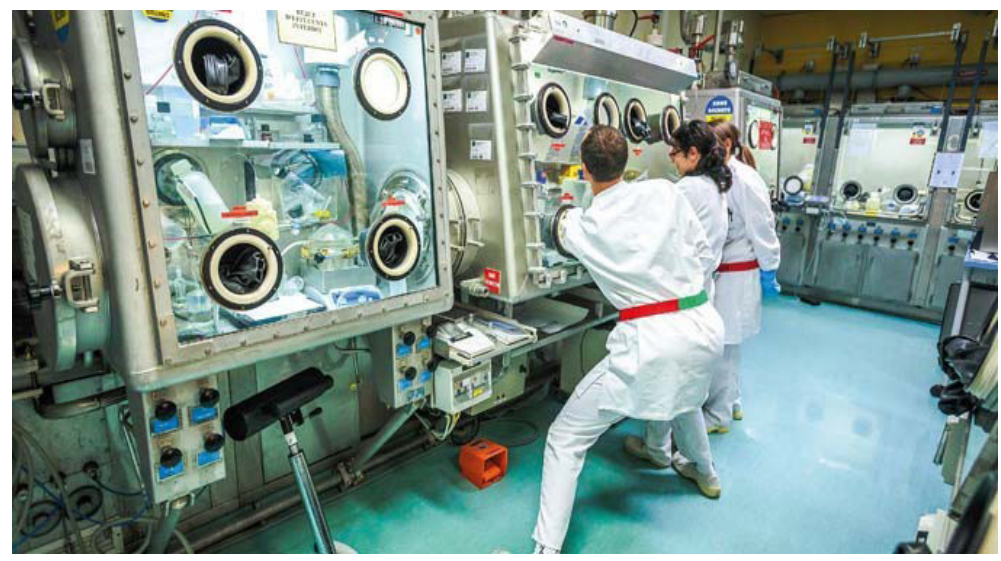

Source: SFEN (2016)

nuclear fuel cycle, and is at the cutting edge of nuclear fuel reprocessing research. With five buildings on a $25,000 \mathrm{~m}^{2}$ campus, each of the buildings handles a stage of the nuclear fuel cycle-dissolution of the nuclear material from spent nuclear fuel, purification of nuclear material, conversion to powdered nuclear materials that can be reused, manufacture of new MOX-type nuclear fuel using that powder, and research on vitrified glass to contain nuclear waste after final processing. There are two hundred people such as engineers and researchers directing experiments and seventy safety officers employed at Atalante.

Atalante has four research policies. First, supplying technologies to Areva to optimize operations of the reprocessing plant at La Hague and the Melox MOX fuel plant at Marcoule. In fact, the description of the Atalante facility states that "Marcoule is the mother of La Hague" and emphasizes that the technical problems that arise at La Hague are analyzed at Marcoule, the results of which are fed back to La Hague. Second, bringing greater efficiency to the nuclear fuel cycle, miniaturization of plutonium extraction facilities, and a reduction of chemical waste in preparation for future fast breeder reactors. Third, the nuclear conversion of minor actinoids. Because long half-life minor actinoids, such as neptunium, americium, and curium, are found in high level radioactive waste, this research aims to convert long-lived dangerous radionuclides to non-radioactive or shortlived nuclides. Fourth, physical chemistry research on glass vitrification of longlived radioactive waste.

Special equipment is always required to mitigate the danger of exposure to radiation during experimental work, typically glove boxes (Figure 3). Radioactive substances are kept in these transparent hermetically sealed boxes to prevent exposure to the outside air, and the gloves are directly attached to the boxes, which enables work isolated from the outside air by utilizing the gloves. There are 
two hundred fifty such glove boxes at Atalante.

Substances that emit strong radiation such as gamma rays cannot be handled in a glove box and work must be done via remotely controlled equipment with the radioactive substance in a space surrounded by thick concrete or lead walls while researchers look on through a peephole. Atalante has eleven rooms with this remotely controlled equipment covering fifty-nine categories.

Reactor Decommissioning Measures: Decommissioning of the military-purpose reactors built at Marcoule was fixed for 1969 for G1, 1980 for G2, and 1984 for G3. The prototype fast breeder reactor Phénix also ceased operations in 2009 and is currently undergoing decommissioning. France's first reprocessing plant UP1 ceased operations in 1997 and is also currently being decommissioned. Looking at the map of the Marcoule site reveals extensive decommissioning work (Figure 4). Built originally for military nuclear purposes, the Marcoule site has become a center for research on the stabilization of civilian-use reactors in their final stages, reactor decommissioning, and reprocessing plant decommissioning.

Case Study of Phénix: As a case study of reactor decommissioning measures at Marcoule, this section provides a review based of the state of Phénix decommissioning based on information gained on a visit to Marcoule in March

Figure 4. Site Map of Marcoule

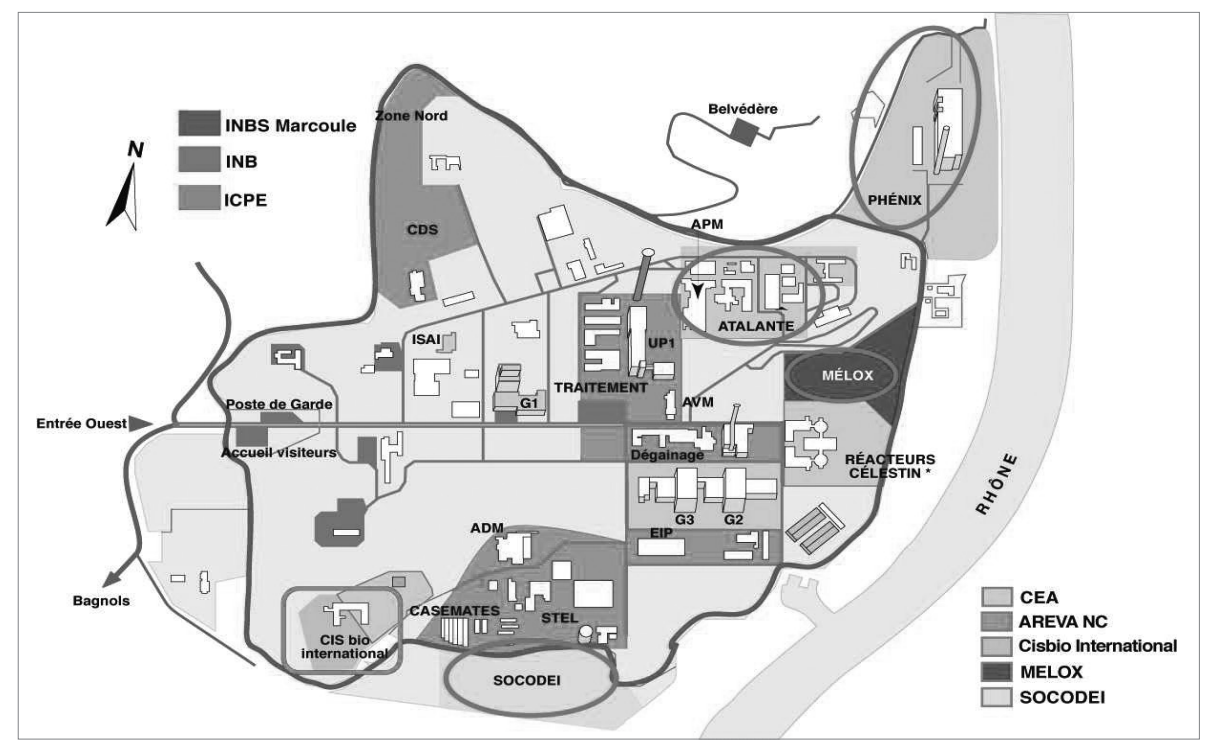

Note: The G1 building is in the center, G2 and G3 are at the lower right, Phénix is in the upper right, and UP1 is at the center right. The Rhone River flows on the right.

Source: HCTISN (2014) 
Figure 5. Phénix Steam Generator Section

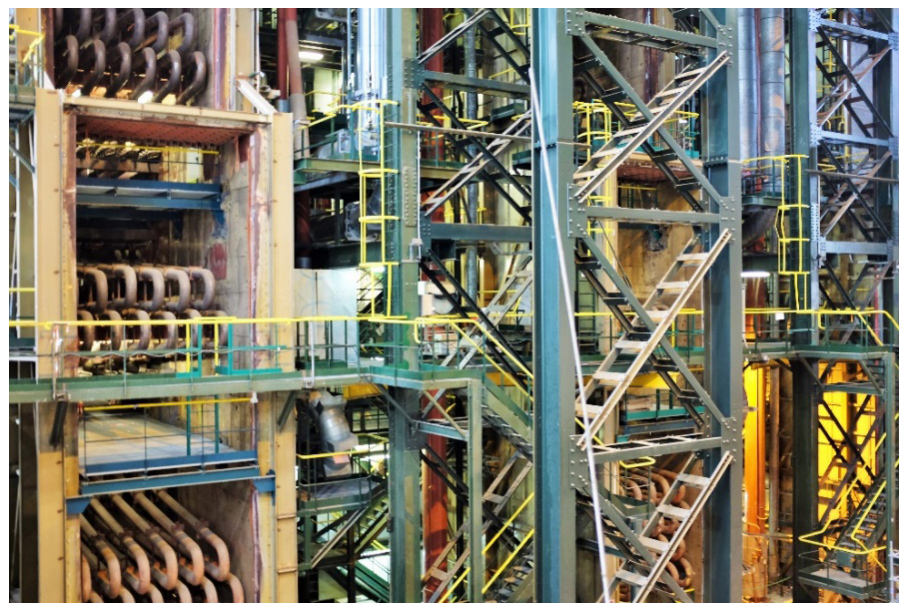

Source: Photographed by the author on March 13, 2015

2015. The photographs included are those that were permitted during the visit.

The CEA has planned the decommissioning of Phénix in six stages (Collet 2016). The first stage involves removing the nuclear fuel from the reactor core, removing the neutron moderation equipment, and removing the removable parts of the reactor core. Completion of nuclear fuel removal is targeted for 2025 , while removal of other equipment is targeted for 2031. The second stage involves dismantling the secondary systems by 2025 , while the third stage involves removal of the sodium coolant and sodium-contaminated metal by 2037. The fourth stage involves processing the sodium remaining in the tanks by 2039 , while the fifth stage involves disassembly of the reactor core and primary systems by 2043 . The final sixth stage involves decontaminating the building and soil by 2050 . The initial plan was to decommission Phénix by 2030, but then an ordinance was issued on June 5, 2016 for complete disassembly by 2045. It is expected that there will be delays in the Phénix decommissioning plan.

The author visited the generator section, the non-operating reactor section, and the reactor control room in March 2015. The steam generator of the generator section still remained (Figure 5), but the turbine has been completely removed to be reused at another power station. The reactor control room is still the same as it was during operations (Figure 6). At the peak of its operations, there were about three hundred people working at Phénix including engineers, administrators, and about thirty researchers involved in nuclear physics.

The Phénix decommissioning is not just a matter of destroying the existing reactor. New facilities have been built at Marcoule for the Phénix decommissioning. One of these facilities is required for stable processing of the recovered sodium. Using a so-called NOAH method, radioactive sodium-22 is 
Figure 6. Phénix Control Room

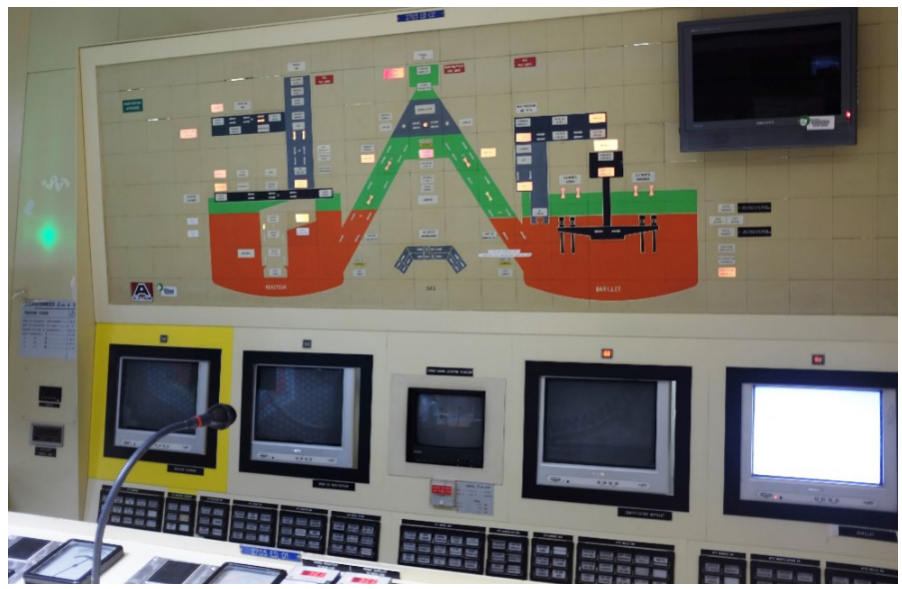

Source: Photographed by the author on March 13, 2015

stored until it reduces to sodium chloride $(\mathrm{NaCl})$ and is then discarded. Another facility is storage for sodium-contaminated metal parts and so forth. Differing from light water reactors that use water as the coolant, fast breeder reactors use sodium coolant which becomes radioactive, and hence require these special facilities when they are decommissioned. In 2016, the Japanese prototype fast breeder reactor Monju was slated for decommissioning and is not hard to imagine that France will offer its Phénix decommissioning technology to Japan.

\section{Conclusion}

In light of the historical development of French nuclear power generation, this article has described the history of the Marcoule Site, a nuclear facility which shifted from military to civilian usage, and which illustrates French nuclear policy as a microcosm. The site started out as a military research facility, and then advanced the nuclear fuel cycle and fast breeder reactor development as a civilian research facility. After nuclear power generation developments stagnated, the facility has focused on researching spent nuclear fuel processing and disposal, as well as plant decommissioning measures. The history of the Marcoule Site shows us the past, present, and future of French nuclear energy development.

Since Monju, a Japanese fast breeder reactor, was slated for decommissioning in 2016, participating in the Advanced Sodium Technological Reactor for Industrial Demonstration (ASTRID), a French fast breeder research facility planned for construction at Marcoule, is under consideration in Japan. In the past, joint Japanese-French research has also been conducted at Marcoule and 
there is a high possibility that Japan will join the ASTRID plan.

\section{Acknowledgement}

This article was originally published in Japanese entitled "France Marcoule site no rekisi - Kaku gunjiriyo kara minjiriyo eno henkan" [History of Marcoule Nuclear Site in France: Transition from Military to Civilian Use] in Yuji Wakao and Eiichi Kido eds., Kaku kaihatsu jidai no isan - Mirai sekinin wo tou [The Legacy of the Era of Nuclear Development: the Responsibility for the Future], Kyoto: Showado, 2017. It has been revised and updated for the English version.

\section{Notes}

1. Chicago Pile-1 (CP-1), the world's first nuclear reactor, succeeded at the University of Chicago on December 2, 1942 and it used graphite to serve as moderators.

2. Information from an interview by the author with Laurant Turpin, director of the CEA affiliated Institut national des sciences et techniques nucléaires (INSTN) on October 2, 2009.

3. Areva decontamination equipment for high-level radioactive waste water treatment costing JPY\$ 6 billion deployed at the Tokyo Electric Power Company Fukushima Daiichi plant was not used after September 2011 (Asahi Shimbum 2011).

4. On March 3, 2010, the CEA changed its name for the first time since its 1945 establishment, from Commissariat à l'énergie atomique to Commissariat à l'énergie atomique et aux énergies alternatives (Areva Activité 2013).

5. The author interviewed Joël Guidez on November 2, 2015, who was the Phénix director from 2002 to 2008, during preparations to recommence operations and after they recommenced. He stated that due to the decommissioning of Superphénix, its associated research activities were carried over to Phénix after its operations recommenced.

\section{References}

American Nuclear Society. 2019. “Nuclear Historic Landmark Award.” http://www.ans.org/ honors/recipients/va-nuclandmark (accessed April 25, 2019).

Areva Actualité. 2013. http://www.areva.com/FR/actualites (accessed April 26, 2019).

Asahi Shimbun. 2011. "JPY 6 Billion French Equipment Retired, Difficulties with High Concentration Liquid Waste, Low Running Efficiency at Fukushima Daiichi Plant." January 30.

Bonnet, Paul. 1982. Pourquoi lénergie nucléaire? [Why Nuclear Energy?]. Paris: Eyrolles.

Capelle-Blancard, Gunther, and Stéphanie Monjon. 1999. "Lindustire nucléaire en France."

[Nuclear Industry in France]. In Le nucléaire à la croisée des chemin [The Nuclear at a Crossroads], ed. Marie-Hélène Labbe, 27-53. Paris: La Documentation française. 
CEA (Commissariat à l'énergie atomique) [The French Atomic Energy Commission]. 1952. Rapport d'activité du CEA.

CEA (Commissariat à l'énergie atomique) [The French Atomic Energy Commission]. 1964. Rapport d'activité du CEA.

CEA (Commissariat à lénergie atomique) [The French Atomic Energy Commission]. 1970. Rapport d'activité du CEA.

CEA (Commissariat à lénergie atomique) [The French Atomic Energy Commission]. 2017. “Les centres CEA" [The CEA Centers]. May 9. http://www.cea.fr/Pages/le-cea/lescentres-cea.aspx (accessed April 25, 2019).

COE-INES. 2007. "Participatory Decision-Making for Final Disposal Site" Report. September 6. Prepared for International Symposium, Centennial Hall, Tokyo Institute of Technology.

Collet, Philippe. 2016. "Nucléaire: le démantèlement du réacteur Phénix est lancé” [Nuclear: The Decommissioning of the Phénix Reactor Has Begun]. Actu-Environnement, June 7. http://www.actu-environnement.com/ae/news/decret-demantelement-reacteurmarcoule-26950.php4 (accessed April 26, 2019).

Debeir, Jean-Claude, Jean-Paul Deléage, and Daniel Hémery. 1986. Les Servitudes de la puissance [The Servitudes of the Power]. Paris: Flammarion.

Denki Shimbun Overseas Nuclear Power Coverage Team. 2006. The Nuclear Renaissance Wind. Denki Shimbun Books: The Japan Electric Association.

Ferrair, A., N. Sugier, and L. Vautrey. 1979. "Le développement des réacteurs à neutrons rapide, les programmes français et étrangers" [The Development of the Fast Neutron Reactors Program in France as well as in Foreign Countries]. R.G.N 6: 582-596.

Framatome. 1995. Framatome. Paris: Albin Michel.

Goldschmidt, Bertrand. 1967. Les rivalités atomiques 1939-1966 [Atomic Rivals 19391966]. Paris: Fayard.

Goldschmidt, Bertrand. 1984. Le Complexe Atomique [The Atomic Complex]. Tokyo: Denryoku-Shinho.

Goldschmidt, Bertrand. 1987. Pionniers de l'Atome [The Pioneers of the Atom]. Paris: Stock.

Guidez, Joël. 2013. Phénix. Saint-Paul-Trois-Châteaux: EDP Sciences.

Guidez, Joël. 2016. Superphénix. Paris: Atlantis Press.

Hecht, Gabrielle. 1998. The Radiance of France. Cambridge, MA: MIT Press.

HCTISN (Haut Comité pour la Transparence et l'Information sur la Sécurité Nucléaire). 2014. "Site de Marcoule" [Marcoule Site]. August 1. http://www.hctisn.fr/article. php3?id_article=127 (accessed April 26, 2019).

JAIA (Japan Atomic Industry Association). 2016. "Japan Atomic Industry Association, Press Release.” March 31. http://www.jaif.or.jp/cms_admin/wp-content/uploads/ 2016/03/doukou2016-press_release.pdf (accessed April 26, 2019).

JAIF (Japan Atomic Industrial Forum). 2019. “Japan Atomic Industrial Forum.” https:// www.jaif.or.jp/cms_admin/wp-content/uploads/2019/01/worldnuclear20190314.pdf (accessed April 26, 2019).

Kojima, Chieko. 2009. "The History of Fast Breeder Reactor Development in France." Humanities and Sciences 15 (1): 1-39.

Kojima, Chieko. 2011. "Interview with the Father of the Fast Breeder Reactor, Georges Vendryes: How Were Nuclear Developments Promoted in France?” Humanities and 


\section{Chieko Kojima}

Sciences 17 (2): 65-86.

Le Midi Libre. 1957. February 26.

Lovéreni, Marie-José. 1996. L’atome de la recherché à l'industrie [The Atom from Research to Industry]. Paris: Gallimard.

Mazzucchetti, Denis. 2005. De divergences en convergences [From Divergences to Convergences]. Sommières: Romain Pages Éditions.

Morsel, Henri. 1996. Histoire de l'Électricité en France [History of Electricity in France]. Vol. 3. Paris: Fayard.

Onishi, Kenichi. 2013. "The Electric Power Situation in France, a Nuclear Energy Superpower." Ba 6: 14-15.

PEON (La Production d'Electricite d'Origine Nucleare Commission). 1968. "Les perspectives de développement des centrales nucléaires, avril 1968" [The Perspectives of Nuclear Plant Development]. Les Dossiers de lénergie, Vol. 1, 57. Paris: PEON.

Perrin, Francis. 1953. "Le plan quinquennal du Commissariat à l'Energie Atomique" [FiveYear Plan of Atomic Energy Commission]. Atomes 85 (4): 111-112.

RFE (Revue francaise de lénergie). 1957. "Les programmes atomiques français au conseil économique" [The French Atomic Energy Programs on the Economic Council]. Revue française de lénergie 90 (10): 27-39.

Sauvage, Jean-François. 2009. Phénix, une histoire de coeur et dénergie [Phénix, A History of Heart and of Energy]. Saint-Paul-Trois-Châteaux: CEA Valrhô.

Scheinman, Lawrence. 1965. Atomic Energy Policy in France under the Fourth Republic. Princeton, NJ: Princeton University Press.

SFEN (Société Française d'Energie Nucléaire). 2016. “Atalante, l'innovation au cœur du cycle du combustible nucléaire" [Atalante, Innovation at the Heart of the Nuclear Fuel Cycle]. http://www.sfen.org/fr/rgn/atalante-linnovation-au-coeur-du-cycle-ducombustible-nucleaire (accessed April 25, 2019).

Vendryes, Georges. 1997. Superphénix pourquoi? [Why Superphénix?]. Paris: Nucléon.

Yazawa, Kiyoshi. 2008. The Nuclear Renaissance. Tokyo: Gijutsu Hyoronsha.

Yoshioka, Hitoshi. 2009. “Trends in Global Nuclear Power Generation and Nuclear Power Policy Direction in Japan." Urban Problems 100 (11): 72-81.

Chieko Kojima studied at Fondation Louis de Broglie in Paris as a French Government scholarship foreign student from 1991 to 1993, received a Ph.D. in Science from Nihon University, Tokyo in 2005 with the dissertation "History of Quantum Theory in France." She is currently teaching history of science and technology as a professor at Nihon University College of Commerce in Tokyo. 